\title{
The Psychology of Terrorism: An Agenda for the 21st Century
}

\section{Martha Crenshaw}

Political Psychology, Vol. 21, No. 2. (Jun., 2000), pp. 405-420.

Stable URL:

http://links.jstor.org/sici?sici=0162-895X\%28200006\%2921\%3A2\%3C405\%3ATPOTAA\%3E2.0.CO\%3B2-A

Political Psychology is currently published by International Society of Political Psychology.

Your use of the JSTOR archive indicates your acceptance of JSTOR's Terms and Conditions of Use, available at

http://www.jstor.org/about/terms.html. JSTOR's Terms and Conditions of Use provides, in part, that unless you have obtained prior permission, you may not download an entire issue of a journal or multiple copies of articles, and you may use content in the JSTOR archive only for your personal, non-commercial use.

Please contact the publisher regarding any further use of this work. Publisher contact information may be obtained at http://www.jstor.org/journals/ispp.html.

Each copy of any part of a JSTOR transmission must contain the same copyright notice that appears on the screen or printed page of such transmission.

JSTOR is an independent not-for-profit organization dedicated to and preserving a digital archive of scholarly journals. For more information regarding JSTOR, please contact support@jstor.org. 


\title{
The Psychology of Terrorism: An Agenda for the 21st Century
}

\author{
Martha Crenshaw \\ Department of Government \\ Wesleyan University
}

\begin{abstract}
Research on political terrorism, which began in the early 1970s, faces some persistent problems. These involve defining the concept, collecting empirical data, building integrative theory, and avoiding the attribution of terrorism to personality disorders or "irrationality." Furthermore, analysis risks being driven by events or the concerns of policymakers. Nevertheless, it is generally accepted that psychological explanations of terrorism must take multiple levels of analysis into account, linking the individual to the group and to society. Future research should critically examine the assumption that a "new terrorism" has appeared at the end of the 20th century. Analysts should also take advantage of 30 years of history to develop comparisons and developmental studies that look not only at the causes of terrorism but at changes in terrorist strategy, the termination of terrorist campaigns, government decision-making, and policy effectiveness.
\end{abstract}

KEY WORDS: terrorism, research, public policy.

The record of research on political terrorism is mixed. Despite progress in developing an explanatory model that links individual, group, and societal levels of analysis, some issues are persistently troublesome. Enduring questions involve the definition of terrorism, the use of research for public policy purposes, the collection of empirical data, the attribution of terrorism to personality disorders or "irrational" thinking, the need for integrative and cumulative theory, and the event-driven character of much research. Although progress is apparent in all of these areas, more work needs to be done. In addition, research on terrorism has not yet fully considered the implications of recent claims that a "new" terrorism has developed in recent years and will prevail in the near future. However, it is encouraging to note that more than 30 years of historical experience with terrorism has opened interesting possibilities for research programs. Comparisons and developmental studies can analyze how patterns of terrorism have changed over time, 
how campaigns of terrorism come to an end, government decision-making processes, and the effectiveness of different counterterrorist policy options.

\section{Persistent Issues}

In 1990, a volume on the psychology of terrorism concluded with two essays on the opportunities for and limitations on future research (Crenshaw, 1990; Reich, 1990). Many of the issues noted then remain on today's research agenda, although there have been substantial changes in the political environment for the study of terrorism and in the depth of knowledge acquired.

The problem of defining terrorism has hindered analysis since the inception of studies of terrorism in the early 1970s. One set of problems is due to the fact that the concept of terrorism is deeply contested. The use of the term is often polemical and rhetorical. It can be a pejorative label, meant to condemn an opponent's cause as illegitimate rather than describe behavior. Moreover, even if the term is used objectively as an analytical tool, it is still difficult to arrive at a satisfactory definition that distinguishes terrorism from other violent phenomena. In principle, terrorism is deliberate and systematic violence performed by small numbers of people, whereas communal violence is spontaneous, sporadic, and requires mass participation. The purpose of terrorism is to intimidate a watching popular audience by harming only a few, whereas genocide is the elimination of entire communities. Terrorism is meant to hurt, not to destroy. Terrorism is preeminently political and symbolic, whereas guerrilla warfare is a military activity. Repressive "terror" from above is the action of those in power, whereas terrorism is a clandestine resistance to authority. Yet in practice, events cannot always be precisely categorized.

Furthermore, even within the terms of this definition, the practice of terrorism is highly diverse. The conceptual category of "terrorism" encompasses a wide variety of phenomena, ranging from kidnappings of individuals (in order to pressure governments to accede to specific political demands) to indiscriminate mass-casualty bombings of high-profile symbolic targets. Terrorism occurs in widely different cultural settings. Non-governments may practice coercion and repression in areas under their control. States may sponsor surreptitious violence against the civilian populations of their enemies. Moreover, even though the scope of the term is already broad, observers are tempted to stretch the concept even further. One often sees references to crime, "narcoterrorism," and "cyberterrorism," for example, not to mention "ecoterrorism" or cultural, olfactory, or nutritional terrorism. In addition, terrorism is a deeply contested concept. Its use tends to be politicized and subjective. It is a pejorative label as much as an analytical tool, especially in popular discourse.

These conceptual confusions remain after more than 25 years of research, but the ideological contentiousness of the term has diminished with the end of the Cold War. The disappearance of the left-wing revolutionary and anti-imperialist movements that inspired much of the ideological and nationalist terrorism of the 1970s 
and early 1980s has led to a change of tone. Nevertheless, in 1999, the heated public debate over President Clinton's offer of clemency to Puerto Rican nationalists serving prison sentences for actions associated with a pro-independence terrorist campaign demonstrates that the term still carries emotional weight. Perceptions of the rightness of the means are altered by judgments about the legitimacy of the cause.

A second issue from the past concerns the possible uses of psychological research on terrorism. Obviously counterterrorism is a major concern of governments, especially the contemporary American government, which has at least 30 different bureaucracies dealing with the issue, including not only intelligence and law enforcement agencies but the Departments of Health and Human Services and Defense. In the 1990s terrorism came to be seen as a major national security threat and thus a subject of intense interest. In 1998, for example, President Clinton appointed a National Coordinator for Security, Infrastructure, Protection, and Counterterrorism. Alexander George (1993) has called for "bridging the gap" to bring about closer collaboration between academics and policymakers in the field of foreign affairs, but he also cautioned that the task of the academic is to diagnose problems rather than prescribe solutions. The scholar should produce "generic knowledge" rather than specific policy recommendations. Before the end of the Cold War, academics were likely to be extremely sensitive to potential ethical dilemmas caused by government use of their research, even if their contributions were limited to diagnosis rather than prescription. However, with the development of a post-Cold War American foreign policy aimed at spreading democracy rather than containing communism, and with the emergence of terrorism from the radical right in the United States, scholars appear less apprehensive about the uses of their knowledge of terrorism. Concern with terrorism is no longer seen as fundamentally illiberal or reactionary (but see Zulaika \& Douglass, 1996).

One source of tension, however, is some policymakers' insistence on the possibility of a fixed and unambiguous "terrorist profile," a list of characteristics that permit identification of actual or potential terrorists. This debate is closely related to the issue of personality theories of terrorism and particularly to the idea that there is a specific psychopathology of terrorism. Silke (1998) deplored a "diagnosis at a distance" tendency to see terrorists as motivated by personality disorders such as narcissism or paranoia. He suggested that although most observers reject the thesis of "blatant" abnormality, there remains a pervasive perception that terrorists are abnormal in more subtle ways. Silke cited Post (1990) and Pearlstein (1991) as examples of such attempts to distinguish terrorists psychologically from the general population. Pearlstein, for example, concluded that "the individual who becomes and remains a political terrorist generally appears to be psychologically molded by certain narcissistic personality disturbances" (1991, p. ix). Silke argued that this misleading trend is a result of attribution bias and that it has done little but "taint terrorism with a pathology aura" (1998, p. 67). 
A related issue is the question of a distinctive psychology or psychopathology of women participants in terrorism. Pearlstein (1991) included female terrorists as prominent cases in his analysis. For example, he argued that Ulrike Meinhof, a founding member of the German Red Army Faction, suffered numerous traumatic events in her life that damaged her self-esteem and led to an obsession with belonging and approval. Profound narcissistic disappointment-her failure to live up to the standards of behavior required by her ego ideal-led her to a terrorist identity. Pearlstein (1991) also analyzed two women activists in the Weathermen, Susan Stern and Diana Oughton. In both cases, he identified childhood and adolescent psychic injuries that led to low self-esteem. Radical political action provided powerful psychological rewards, such as the acquisition of a new positive identity.

However, in an analysis of women in Japanese terrorist organizations, Steinhoff (1996) noted that the public and psychiatrists alike tend to attribute mental illness to female terrorists, who stand as "the negative image of everything women are not supposed to be" (p. 319). She cited the example of Hiroka Nagata of the United Red Army and the notoriously bloody purge that occurred within the organization's ranks in the spring of 1972. Whereas the male leader of the purging faction was described by the press and psychiatrists as an instrumentally motivated person who had merely miscalculated, the female leader (Nagata) was said to be purely emotional-spiteful, jealous, menacing, and mentally unbalanced. Steinhoff quoted the judge's trial opinion: "[Nagata] has a flourishing desire for self-exposure and along with an emotional, aggressive personality, she is suspicious and jealous, and to these are added the female characteristics of obstinacy, spitefulness, and cruel sadism; she harbors a variety of problems in her temperament" (1996, p. 311).

De Cataldo Neuberger and Valentini (1996) suggested that female terrorism is linked to childhood maladjustment resulting from an unfeeling, tyrannical father and a weak mother. Their findings, based on interviews with female terrorists in Italy, indicate that greater passivity in women results in a longer adolescent identification period than that experienced by boys; girls need to bond with their mothers for an extended period of time in order to develop and adapt. During this stage, developmental problems may occur that later lead to entry into terrorist groups. Such maladjusted girls, who identify with their weak mothers, are more inclined to engage in splitting, and, in their bifurcated view of the world, compassion and tolerance of others are lost. Young women then shift their identifications outside the family and search for a "weak person" to love and save. They are, consequently, susceptible to the appeals of a terrorist organization that pursues the destruction of the strong who oppress the weak. The female terrorist thus demonstrates her father's strength as well as the sacrificial attitude of the mother.

These authors also suggested that a "maternal-sacrificial code" is highly developed in women because of their childhood development, the patriarchal pressures of society, and their genetic disposition to protect and sacrifice for their 
children (de Cataldo Neuberger \& Valentini, 1996, pp. 78-81). This "feminine 'way of living'" predisposes women to develop their experience in accordance with sacrifice and caring for others. This maternal code is apparently the "something extra" that makes female terrorists more willing to sacrifice their lives in the name of the group.

Nevertheless, most analysts of terrorism do not think that personality factors account for terrorist behavior, nor do they see significant gender differences. One of the basic research findings of the field is that terrorism is primarily a group activity. It is typically not the result of psychopathology or a single personality type. Shared ideological commitment and group solidarity are much more important determinants of terrorist behavior than individual characteristics. After an extensive review of the literature, Ross (1994) concluded that psychological explanations of terrorism were still immature, but he suggested an integrated theory in which individuals who are predisposed to engage in terrorism due to developmental factors find certain needs satisfied by joining underground groups. For example, Braungart and Braungart (1992) concluded that the developmental processes of youth explained the Weathermen better than individual psychological attributes. Once in the group, socialization and learning experiences further shape the behavior of terrorists. They also interact with constituents, rival groups, and the government they oppose. (See also Sprinzak, 1990, who focused on group identification processes.) Thus, terrorism must be seen as an interactive and dynamic process, as Rabbie (1991) effectively argued in proposing a preliminary descriptive model that links individual, group, and societal levels of analysis.

Della Porta $(1992,1995 a, 1995 b)$ also proposed a more complex framework that links individual life histories to political and social environments. She focused on individual perceptions of external opportunities presented by the environment. In this approach, the critical step is the choice of clandestinity. She also noted the persistence of individual commitment to underground organizations, a commitment that is best explained by intense identification with the group. Commitment is also motivated by ego-involvement. Individuals seek to maintain self-respect, the support of the peer group, and the sense of belonging that is heightened by a sense of shared risk. Della Porta's research shows not only that individual motivations and structural conditions must be analyzed together, but also that the individuals in question possessed well-established political identities and had experienced prior socialization into the use of violence. Their commitment to terrorism was the result of a gradual process, not a sudden conversion. In particular, they shared the image of a violent state and participation in semi-legal protest movements. (On Italian movements, see also Passerini, 1992.)

Bandura (1990) took a different approach to the analysis of individual behavior. He argued that terrorism was the result of a "principled resort to destructiveness" (p. 191) rather than unrestrained impulse, a factor that psychological analyses of violence had ignored. Consequently, he examined the psychological processes by which individuals can disengage the internal regulatory mechanisms that usually 
serve to restrain violence. He identified three major points of development in the self-regulatory process: when reprehensible conduct can be reconstrued as justifiable, its detrimental effects minimized or distorted, and the victim blamed or devalued. In terms of causal agency, he also noted a tendency to displace responsibility onto the enemy or diffuse it within the group.

As Ross and Rabbie both noted, a mature research program requires empirical testing of integrative psychological theories. It is not enough simply to propose hypotheses. The study of terrorism still lacks the foundation of extensive primary data based on interviews and life histories of individuals engaged in terrorism. Far too often, psychological hypotheses are based on speculation or are derived from such a small number of cases that the findings cannot be considered reliable (Pearlstein, 1991, for example, used mostly secondary sources to analyze nine individuals). However, the works of sociologists Juergensmeyer (2000) and della Porta $(1992,1995 a, 1995 b)$ are noteworthy exceptions that demonstrate that it is not impossible to acquire meaningful information about the sources of clandestine violence. Della Porta's studies of left-wing Italian and German terrorists, for example, are based on an extensive collection of life histories, biographies, and autobiographies.

Studies of the psychology of terrorism often focus on the ways in which particular beliefs and misperceptions limit or bound rationality (e.g., Crenshaw, 1992). Yet it is important to remember that terrorism has an autonomous logic that is comprehensible, however unconventional. These belief systems are typically derivative rather than original. Misperception may be acute. However, it is essential to understand the ideologies or worldviews of practitioners of terrorism on their own terms, and not to exclude them from analysis because they appear "irrational" in a conventional sense (see Reich, 1990). For example, Sprinzak's (1990, 1991, 1995) theory of split delegitimization focuses directly on the images of the enemy held by terrorists. He argued that certain groups are organized around the belief that the enemy is illegitimate and thus not human. Violence and terrorism result when the group feels threatened.

Sprinzak (1990) also stressed that the conditions that promote ideological terrorism, especially terrorism from the left in democracies, are not identical to the causes of protest or unconventional political behavior in general. Extraparliamentary political action is an accepted part of the democratic repertoire. Terrorism requires the perception of an unjustly harsh government, profound disillusionment with the existing order, and the availability of appropriate external role models. Most radicals do not become terrorists.

Sprinzak's analytical model was the critical focus of a collection of comparative case studies of right-wing terrorism (Bjørgo, 1995), which claims to be the first of its kind. This relatively recent interest in right-wing terrorism exemplifies the tendency of terrorism studies to be event-driven. In the 1970s and early 1980s, terrorism associated with the far left or nationalist resistance was the center of attention. In the late 1980s and 1990s, interest in terrorism from the extreme right 
attracted notice. In the United States, concern intensified as a result of the 1995 Oklahoma City bombing and the activities of the survivalist, militia, and Christian Identity movements (see Barkun, 1995, 1996). Internationally, Jewish terrorism in Israel and right-wing anti-immigrant violence in Europe also drew attention. This focus on current events, while understandable from psychological and political points of view, can distract researchers from studies that focus on historical developments over time. This reactive quality has also tended somewhat to discredit the study of terrorism, which is seen as trendy and fashionable.

\section{A "New" Terrorism?}

Although the prospect of terrorism from the right had been neglected, analysts could build on a preexisting framework of research on right-wing movements and ideologies. The phenomenon was not perceived as entirely unfamiliar, although far-right violence seemed to be growing more virulent and destructive. However, the question of who is a terrorist has lately taken on a new dimension. Several recent works focus on a "new" terrorism that is motivated by religious belief and is more fanatical, deadly, and pervasive than the older and more instrumental forms of terrorism the world had grown accustomed to (e.g., Laqueur, 1999). This emerging "new" terrorism is thought to differ from the "old" terrorism in terms of goals, methods, and organization (see Hoffman, 1999).

The comparison goes roughly as follows. Whereas the "old" terrorists sought short-term political power through revolution, national liberation, or secession, the "new" terrorists seek to transform the world. Motivated by religious imperatives, they are thought to lack an earthly constituency and thus to feel accountable only to a deity or to some transcendental or mystical idea. Conventional left-right ideological distinctions are not applicable. Because they do not want popular support, they are unlikely to claim public credit for their actions. Also, "new" terrorists are thought to be more inclined to use highly lethal methods in order to destroy an impure world and bring about the apocalypse. The strategies of the "old" terrorists were discriminating; terrorism was a form of communicating a specific message to an audience. Results were anticipated in the here and now. In the "new" terrorism, unlimited ends lead to unlimited means. Thus the "new" terrorists seek to cause high numbers of casualties and are willing to commit suicide or use weapons of mass destruction in order to do so. Finally, whereas traditional militants were linked in tight, centralized, structured conspiracies, the organization of the "new" terrorists is decentralized and diffuse. Adherents are united by common experience or inspiration rather than by direct personal interaction with other members of the group and its leaders. Institutions and organizations are less important than beliefs.

One empirical source of the conception of a "new" terrorism is radical right violence, particularly in the United States. The shock of the 1995 Oklahoma City bombing brought the largely unknown world of the militia movement to international 
attention. Barkun (1996) has argued that belief in a generic conspiracy theory is a common denominator in the diffuse and splintered world of American radical right groups. Although such conspiratorial beliefs are not new in American politics, what distinguishes the 1990s doctrinal framework is its specificity and the ease with which it can be given a religious interpretation (see also Kaplan, 1995). The conspiratorial right believes not only that a cabal is promoting a tyrannical "New World Order" under the direction of the United Nations but that it is close to victory, thus necessitating an immediate defense. The violent encounters at Ruby Ridge (1992) and Waco (1993) are interpreted as confirmation of the conspiracy's sinister intent. The incidents also drive an intense sense of martyrdom. These belief systems contain apocalyptic religious elements; the "New World Order" is often depicted as the creation of the Antichrist. Many extreme right groups and leaders are affiliated with the Christian Identity movement. Thus, secular and religious beliefs constitute two intersecting and reinforcing conspiratorial visions. The fact that these ideas are rejected by established institutions of society only makes them all the more credible to conspiratorialists; they are validated by their rejection. (It should be noted that violence from the radical right has also occurred in Europe, especially violence against foreigners. However, it tends to lack the apocalyptic religious overtones of the American subculture.) It is important to remember, however, that the Oklahoma City bombing is the only act of mass-casualty terrorism perpetrated by the American extreme right.

An earlier and more violent historical antecedent of the conception of a "new" terrorism is anti-Western terrorism originating in the Middle East that is linked to radical or "fundamentalist" Islam. This concern dates from the 1980s and terrorism attributed to the Shi' ite Hezbollah faction in Lebanon. In the 1990s, terrorism using the rhetoric and discourse of Islam sprang from Hamas and Islamic Jihad in Israel, the Islamic Group in Egypt, the Armed Islamic Group in Algeria, and most recently the Osama Bin Ladin network. Governments such as the Sudan and Afghanistan seemed to support the trend. Alarm over the emergence of radical Islam (which is a small minority of the Muslim world) was heightened by a combination of factors: the resort to suicide bombings in Lebanon and Israel (see Merari, 1990), a general willingness to inflict mass civilian casualties, and anti-American and anti-Western targeting patterns. The bombing of the World Trade Center in 1993 as well as the bombings of the American embassies in Kenya and Tanzania in 1998 further increased the American sense of vulnerability.

Of course, the general concept of religious terrorism is not restricted to Islam, however common the association is in the popular press. It includes Jewish, Christian, and Sikh faiths as well, all of which have inspired terrorism in the 1980s and 1990s (see Juergensmeyer, 1991, 2000). For instance, Juergensmeyer (2000) employs a cultural approach to explaining religious violence, comparing Christian, Muslim, Sikh and Buddhist activists who either use or espouse violence. Focusing on their shared worldviews or mindsets, Juergensmeyer finds common patterns of imagery and justification. An image of cosmic struggle, for example, gives meaning 
to experiences of deprivation and militant movements that are marginalized in terms of mainstream religion.

Against this background of anxiety about religious terrorism, the 1995 sarin gas attack on the Tokyo subways by the Aum Shinrikyo cult was exceptionally alarming. It bolstered anticipation of catastrophic terrorism intended to bring about the apocalypse. It also introduced the prospect of religious cults as terrorist actors, as opposed to movements that linked nationalism and religion. Robert Jay Lifton (1999) concluded that the link between religious cults and the use of weapons of mass destruction indicated a future escalation of terrorism to unprecedented and fearsome levels. With the combination of fanaticism and the ultimate weapon, a threshold was crossed. This anticipation now pervades the literature. Since 1995, studies of the potential for such "WMD" terrorism have proliferated. In the absence of concrete information on possible motivations, most studies focus instead on opportunity and capability (see Falkenrath, Newman, \& Thayer, 1998; Laqueur, 1999; Stern, 1999). In government circles, anticipation has become near certainty.

What psychological evidence exists to support the prediction that religious terrorists will seek to cause catastrophic destruction, particularly using biological, chemical, radiological, or nuclear means? So far the only explicitly psychological analysis is that of Lifton (1999), whose findings are based primarily on interviews with lower level members of Aum Shinrikyo as well as press and other observer accounts. The members of Aum tended to be people who had long searched for spiritual commitment, particularly of a New Age sort. They had often been restless members of other fringe cults, not political activists. The belief system of the group was wildly eclectic, to the point of incoherence. Although Lifton's approach was basically psychoanalytic, he interpreted their commitment in terms of social relationships within the cult and the leader's charismatic authority. Once in the group, obedience to the charismatic leader (Shoko Asahara) became obligatory and absolute. If obedience was not voluntary, it was coerced. Lifton compared Aum Shinrikyo to other religious cults, such as Heaven's Gate, the Branch Davidians, and the People's Temple in Jonestown, all of which also turned to what Lifton called "revolutionary suicide." Yet Lifton concluded that even though Aum's was the strangest and most bizarre behavior he had ever studied, still the cult had a prosaic side $(1999$, p. 341$)$. He was struck by the "familiar ordinariness" of most of its members and their everyday life.

The emphasis on a "new" terrorism suggests a number of issues. Is the Aum Shinrikyo cult typical of a genre of terrorists about whom generalizations about motivation can be offered? Is it really representative of the "new" terrorism, as Lifton and many others suggest? Or is it unusual in terms of resources, leadership, and historical and social context? It does not fit the "new" terrorism criterion of a decentralized movement, and the cult was a legal organization, not an illegal underground.

Thus, within the category of the "new" terrorism, even if a common motivation is assumed, different organizational structures are present. What impact will they 
have on behavior? Sprinzak (1995) suggested that in poorly organized radical subcultures, the epitome of the "new" terrorism, personality characteristics (particularly those of leaders) become more important than sociopolitical factors. But is it possible for a charismatic leader to exert authority over a decentralized group, in the absence of personal contact between leaders and followers? Charismatic leadership, as found in Aum, is probably more characteristic of closed organizations. Most past research findings are based on data from clandestine undergrounds: closed groups that are typically in competition with each other, whose members experience strong group solidarity and peer pressure, feel intense personal loyalty to each other, merge individual identity in the group, and display distorted perceptions of the outside world. They are also fundamentally political, even if they see the authorities as illegitimate. Which of the old findings will apply to groups such as the Osama Bin Ladin network? Although some militants interact in training camps in Afghanistan, most seem to be bound more by past experience (fighting against the Soviet Union in Afghanistan) and shared beliefs than by direct contact with each other. Little is known about the psychology of militants who operate independently of a group and who seem to be motivated by ideological inspiration rather than direct orders.

Moreover, groups classed together as possessing religious belief systems display different levels of social rootedness. Some groups are isolated from society, but others are part of social movements with substantial popular support and outreach programs (such as Hamas). Nor can one infer individual motivation directly from group ideology.

Given these differences in organizational structure and social context, the assumption of the inevitability of imitation should be questioned. The mechanisms of contagion of methods of violence are not fully understood. The 1995 Tokyo subway attack does not appear to have established a precedent. Is the desire to cause mass casualties necessarily linked to weapons of mass destruction, or do they have a unique appeal? What causes the violation of norms or taboos that prohibit the use of these weapons? Would the use of "WMD" require greater moral disengagement than the use of conventional weapons? Are bombings of greater psychological value than biological or chemical "poisonings" (see Stern, 1999)?

Similarly, is suicidal violence or the willingness to cause mass casualties necessarily linked to religious goals? The Liberation Tigers of Tamil Eelam (LTTE), a resolutely secular nationalist group, has practiced the human bomb technique for more than 20 years. In December 1999, for example, during a presidential election campaign, two different LTTE squads attempted simultaneously to assassinate the president of Sri Lanka and the leader of a competing political party. Their bombs have often caused large numbers of civilian casualties. Hoffman (1999) sees the LTTE as representative of a new trend toward a "professionalization" of terrorism, whereas religious terrorists are more likely to be amateur. 
The absence of empirical evidence for many claims about a "new" terrorism, particularly the likelihood of the use of weapons of mass destruction, raises more questions. Both the study of terrorism and counterterrorism policy have been event-driven. Why has the notion of a "new," dangerous, and uncontrollable terrorism become so compelling? Is the perception driven by the shock of a series of events closely related in time but not necessarily caused by the same factors? Is the perception of threat driven by public opinion, the news media, or elites in the government and scientific communities? Stern (1999) suggested that people fear death by poison and thus experience a special sense of "dread" at the prospect of chemical or biological attack. Johnson (1994) argued that exaggeration of threats is likely when people fear loss of order and control, because of a need for certainty and predictability. The perception of particularly vivid or salient threats may be exaggerated, especially when there is little information about them. The assumed potential destructiveness of chemical or biological terrorism (which is actually the subject of scientific dispute) may cause an overestimation of its likelihood. Furthermore, there has been little psychological study of public reactions to "conventional" terrorism, outside of some work on the Israeli case (see Kaufman, 1991, who found that the public tends to misperceive adversary intentions).

\section{New Possibilities for Research}

The study of terrorism should go beyond a concentration on current events or speculation about the future to develop systematic analyses of the development of the phenomenon over time. Researchers now have a wealth of evidence on the basis of which generalizations can be constructed. Psychology could contribute to answering a number of important questions, most of which have only rarely been addressed directly.

First, little is known about why the users of terrorism would abandon the strategy. Research has focused on the psychological motivations for engaging in terrorism rather than motivations for renouncing terrorism. Yet a number of protracted terrorist campaigns have ended by the deliberate decision of participants (for example, the Provisional Irish Republican Army or the Popular Front for the Liberation of Palestine, in the context of wider peacemaking processes). It is generally accepted that terrorists do not "win" in an objective or material sense. Analysis, however, should focus on terrorist perceptions of goals and of the effectiveness of terrorism as a strategy. Research should try to identify the psychological incentives for giving up violence. For example, do groups that abandon violence perceive that terrorism has failed (for example, in causing the withdrawal of popular support or the onset of demoralization within the group), or do they notice new opportunities for achieving their objectives? What are the psychological costs of participating in terrorism? What leads individuals to accept offers of reduced prison sentences (such as the pentiti in Italy) or amnesties? Is the decision to renounce terrorism the result of an individual or a group process? Does it involve 
a reactivation of moral self-evaluation, a reversal of the moral disengagement processes that Bandura (1990) identified? Governments often assume that terrorism can be decisively defeated through a forceful and punitive response, but in some cases a policy of deterrence only seems to reinforce terrorist beliefs. How do terrorists perceive government actions?

A second area for fruitful research concerns the development of strategies of terrorism. In particular, what leads to innovation in terrorist behavior, such as hostage-takings or the resort to weapons of mass destruction? Psychological theory proposes that innovations are not leaps into the unknown; they arise from new ways of associating previously known ideas or reconstructing familiar methods (see Feldman, Csikszentmihalyi, \& Gardner, 1994; Sternberg, 1988). Innovation is the result of a gradual learning process, not a sudden burst of enlightenment. What is required is a redefinition or reconceptualization of an old problem, based on knowledge and experience. According to Holyoak and Thagard (1995), "mental leaps" occur when an individual is confronted by an unfamiliar situation, when the environment seems disordered and confused. Pressed to work quickly, the decisionmaker must move between a "source analog," the known and familiar domain of experience and knowledge, and a "target analog," the new puzzle. Selecting a specific source analog, however, is not simple; many potential sources of analogies lie in memory and experience, and their connection to the present is not automatic. Some sources originate when they are "noticed" by a decision-maker through serendipity or accident (Holyoak \& Thagard, 1995, p. 192). A variety of psychological factors may make an available source salient, such as events personally experienced or incidents that are emotionally compelling. An event that stimulated a desire for revenge might be a significant cue for innovation, for example. It is also likely to be linked to the factor of leadership and the determination to solve a particular problem.

Another research area that has been neglected is the study of decision-making in the area of counterterrorism (see also Crenshaw, 1990). Hermann and Hermann (1990) studied the relationship between hostage-takings and stress in presidential decision-making. The question of the psychology of governmental response takes on special urgency when the use of military force is an option. In particular, research should investigate inconsistencies in counterterrorist policy and reactions to the threat of catastrophic terrorism. For example, before the 1998 bombings in East Africa, the Clinton administration had taken a low-key, even minimalist, approach to terrorism. The issue was typically mentioned as one item in a list of "transnational" or "border-crossing" policy problems, including epidemics of disease, global organized crime, drugs, and environmental disasters. The administration had also been philosophically averse to the use of force in foreign policy. Yet its response to the bombings was to launch cruise missiles against training camps in Afghanistan and against a pharmaceuticals plant in the Sudan suspected of manufacturing chemical precursors for the development of chemical weapons. 
The decision to strike the pharmaceuticals plant was highly controversial within and outside the administration.

Many questions remain about the cognitive and emotional biases that might have affected this decision and will likely influence future reactions. How do governments learn from past experiences in dealing with terrorism? What did the Clinton administration learn, for example, from the Reagan administration's bombing of Libya in 1986? How inclusive was the decision-making process? Was dissent encouraged or discouraged? If terrorist adversaries are perceived as irrational fanatics, their motives may not be examined closely. Do policymakers anticipate the effects of their actions on terrorist beliefs and perceptions or appreciate the adversary's construction of reality?

Questions about how terrorism ends and the policymaking process are both related generally to the issue of the effectiveness of government counterterrorism policies. In a psychological analysis of policy effectiveness, Ginges (1997) argued that a strategy of denial and punishment tends to oversimplify terrorist motivations and contribute to a hardening of their resolve, whereas a reintegrative strategy takes into account the terrorists' feelings of rejection and alienation. Like most studies of motivation, his argument is based on familiar groups of the past, such as the Italian Red Brigades. What is needed is an investigation of the effects of different policies on a range of groups with different motivations, organizational structures, and social relationships.

An additional research concern is the public reaction to terrorism. For example, if the United States should experience an incident of chemical or biological terrorism (the scenarios that are considered most likely), how would the public respond? A common assumption in the government is that widespread panic would result, necessitating costly preventive and coping measures, but this projection is not based explicitly on psychological findings or on empirical evidence. Studies of the psychological effects of past mass-casualty bombings would be instructive. Would the reaction to terrorism be more severe than the response to a natural disaster?

\section{Conclusions}

A focus on the prospect of a "new" catastrophic terrorism should not be allowed to distract researchers from basic questions or to obscure the fact that much terrorism is still of the familiar variety, with pragmatic and comprehensible aims. Furthermore, only by comparing the present to the past can research determine what is new. Researchers should also be cautious about drawing inferences about patterns of terrorism from small numbers of cases or constructing general categories of terrorist actors that lump together dissimilar motivations, organizations, resources, and contexts. Although there is still much more to learn about the motivations for terrorism, particularly the sources of escalation, research should not neglect the questions of how terrorism ends or how governments and publics 
respond. Last, the study of psychological motivations for terrorism, as well as for ending terrorism, should continue to be based on a model that integrates the individual, the group, and society. "Terrorists" cannot be considered in isolation from their social and political context.

\section{AUTHOR'S ADDRESS}

Correspondence concerning this article should be sent to Martha Crenshaw, Department of Government, Wesleyan University, Middletown, CT 06459. E-mail: mcrenshaw@wesleyan.edu

\section{REFERENCES}

Bandura, A. (1990). Mechanisms of moral disengagement. In W. Reich (Ed.), Origins of terrorism: Psychologies, ideologies, theologies, states of mind (pp. 161-191). Cambridge: Cambridge University Press.

Barkun, M. (Ed.) (1995). Special issue on Millennialism and Violence. Terrorism and Political Violence, 7(3).

Barkun, M. (1996). Religion, militias and Oklahoma City: The mind of conspiratorialists. Terrorism and Political Violence, 8(1), 50-64.

Bjørgo, T. (Ed.) (1995). Special issue on Terror From the Extreme Right. Terrorism and Political Violence, $7(1)$.

Braungart, R. G., \& Braungart, M. M. (1992). From protest to terrorism: The case of SDS and the Weathermen. In D. della Porta (Ed.), Social movements and violence: Participation in underground organizations (pp. 45-78). Greenwich, CT: JAI Press.

Crenshaw, M. (1990). Questions to be answered, research to be done, knowledge to be applied. In W. Reich (Ed.), Origins of terrorism: Psychologies, ideologies, theologies, states of mind (pp. 247-260). Cambridge: Cambridge University Press.

Crenshaw, M. (1992). Decisions to use terrorism: Psychological constraints on instrumental reasoning. In D. della Porta (Ed.), Social movements and violence: Participation in underground organizations (pp. 29-42). Greenwich, CT: JAI Press.

de Cataldo Neuberger, L., \& Valentini, T. (1996). Women and terrorism. New York: St. Martin's.

della Porta, D. (1992). Political socialization in left-wing underground organizations: Biographies of Italian and German militants. In D. della Porta (Ed.), Social movements and violence: Participation in underground organizations (pp. 259-290). Greenwich, CT: JAI Press.

della Porta, D. (1995a). Left-wing terrorism in Italy. In M. Crenshaw (Ed.), Terrorism in context (pp. 105-159). University Park, PA: Pennsylvania State University Press.

della Porta, D. (1995b). Social movements, political violence, and the state: A comparative analysis of Italy and Germany. Cambridge: Cambridge University Press.

Falkenrath, R. A., Newman, R. D., \& Thayer, B. A. (1998). America's Achilles heel. Cambridge, MA: MIT Press.

Feldman, D. H., Csikszentmihalyi, M., \& Gardner, H. (Eds.) (1994). Changing the world: A framework for the study of creativity. Westport, CT: Praeger.

George, A. (1993). Bridging the gap: Theory and practice of foreign policy. Washington, DC: U.S. Institute of Peace.

Ginges, J. (1997). A psychological evaluation of different strategies for deterring terrorism. Terrorism and Political Violence, 9(1), 170-185. 
Hermann, M., \& Hermann, C. (1990). Hostage taking, the presidency, and stress. In W. Reich (Ed.), Origins of terrorism: Psychologies, ideologies, theologies, states of mind (pp. 211-229). Cambridge: Cambridge University Press.

Hoffman, B. (1999). Terrorism and Weapons of Mass Destruction: An Analysis of Trends and Motivations. P-8039. Santa Monica, CA: Rand.

Holyoak, K. J., \& Thagard, P. (1995). Mental leaps: Analogy in creative thought. Cambridge, MA: MIT Press.

Johnson, R. H. (1994). Improbable dangers: U.S. conceptions of threat in the cold war and after. New York: St. Martin's.

Juergensmeyer, M. (Ed.) (1991). Special issue on Violence and the Sacred in the Modern World. Terrorism and Political Violence, 3(3).

Juergensmeyer, M. (2000). Terror in the mind of God: The global rise of religious violence. Berkeley, CA: University of California Press.

Kaplan, J. (1995). Right-wing violence in North America. Terrorism and Political Violence, 7(1), 44-95.

Kaufman, E. (1991). Israeli perceptions of the Palestinians' "limited violence" in the Intifada. Terrorism and Political Violence, 3(4), 1-38.

Laqueur, W. (1999). The new terrorism: Fanaticism and the arms of mass destruction. New York: Oxford University Press.

Lifton, R. J. (1999). Destroying the world to save it: Aum Shinrikyo, apocalyptic violence, and the new global terrorism. New York: Holt.

Merari, A. (1990). The readiness to kill and die: Suicidal terrorism in the Middle East. In W. Reich (Ed.), Origins of terrorism: Psychologies, ideologies, theologies, states of mind (pp. 192-203). Cambridge: Cambridge University Press.

Passerini, L. (1992). Lacerations in the memory: Women in the Italian underground organizations. In D. della Porta (Ed.), Social movements and violence: Participation in underground organizations (pp. 161-212). Greenwich, CT: JAI Press.

Pearlstein, R. M. (1991). The mind of the political terrorist. Wilmington, DE: Scholarly Resources Inc.

Post, J. M. (1990). Terrorist psycho-logic: Terrorist behavior as a product of psychological forces. In W. Reich (Ed.), Origins of terrorism: Psychologies, ideologies, theologies, states of mind (pp. 25-40). Cambridge: Cambridge University Press.

Rabbie, J. M. (1991). A behavioral interaction model: Toward a social-psychological framework for studying terrorism. Terrorism and Political Violence, 3(4), 134-163.

Reich, W. (1990). Understanding terrorist behavior: The limits and opportunities of psychological inquiry. In W. Reich (Ed.), Origins of terrorism: Psychologies, ideologies, theologies, states of mind (pp. 261-279). Cambridge: Cambridge University Press.

Ross, J.I. (1994). The psychological causes of oppositional political terrorism: Toward an integration of findings. International Journal of Group Tensions, 24, 157-185.

Silke, A. (1998). Cheshire-cat logic: The recurring theme of terrorist abnormality in psychological research. Psychology, Crime \& Law, 4, 51-69.

Sprinzak, E. (1990). The psychopolitical formation of extreme left terrorism in a democracy: The case of the Weathermen. In W. Reich (Ed.), Origins of terrorism: Psychologies, ideologies, theologies, states of mind (pp. 65-85). Cambridge: Cambridge University Press.

Sprinzak, E. (1991). The process of delegitimization: Towards a linkage theory of political terrorism. Terrorism and Political Violence, 3(1), 50-68.

Sprinzak, E. H. (1995). Right-wing terrorism in a comparative perspective: The case of split delegitimization. Terrorism and Political Violence, 7(1), 17-43.

Steinhoff, P. G. (1996). Three women who loved the left: Radical woman leaders in the Japanese Red Army movement. In A. E. Imamura (Ed.), Re-imaging Japanese women (pp. 301-324). Berkeley, CA: University of California Press. 
Stern, J. (1999). The ultimate terrorists. Cambridge, MA: Harvard University Press.

Sternberg, R. J. (Ed.) (1988). The nature of creativity. Cambridge: Cambridge University Press.

Zulaika, J., \& Douglass, W. A. (1996). Terror and taboo: The follies, fables, and faces of terrorism. New York: Routledge. 